\title{
Food Security and Income through Sweet Potato Production in Teso,
} Uganda

\author{
William Faustine Epeju ${ }^{1} \&$ Peter Milton Rukundo ${ }^{2}$ \\ ${ }^{1}$ Department of Agriculture, Faculty of Vocational Studies, Kyambogo University, Uganda \\ ${ }^{2}$ Department of Human Nutrition and Home Economics, Faculty of Vocational Studies, Kyambogo University, \\ P.O.Box 1 Kyambogo, Uganda \\ Correspondence: William Faustine Epeju, Department of Agriculture, Faculty of Vocational Studies, Kyambogo \\ University, P.O.Box 1 Kyambogo, Uganda. Tel: 256-774-160-118. E-mail: wepeju@yahoo.co.uk
}

Received: September 27, 2017 Accepted: October 13, 2017 Online Published: January 13, 2017

doi:10.5539/sar.v7n1p146 URL: https://doi.org/10.5539/sar.v7n1p146

\begin{abstract}
Two relevant studies on food security are referred to in the article. Food insecurity from time to time threatens in Teso sub region which houses a viable Teso agricultural system. One study was done during 2001-2003 in Teso on sweet potato production with 650 persons participating and the second one was done in one disaster affected area of Bududa District nearby during 2012-2016 when 1,142 persons participated. Kiryandongo District where Bududa landslide survivors were resettled in Uganda was included in that study. Participatory methods such as focus group discussions, farm observations, in-depth interviews, and questionnaires were used. Both studies used qualitative and quantitative methods for data analysis. The sweet potato stands second after cassava as the crop for famine and disaster periods in Teso to meet the human right to adequate food to complement the well dried cereals \& grain legumes that stored longer. Livestock especially was also one of the prime determinants of food security and income in Teso. Free from cyanides with a good content of affordable Vitamin A from orange fleshed varieties, sweet potatoes in Teso contributed about $61 \%$ to the yearly food per capita of the population thus a recommendable crop for sustainable food security and some income in Teso and beyond.
\end{abstract}

Keywords: climate change, disaster, farm productivity, food access, food availability, food security, income, policy, right to adequate food, sweet potatoes

\section{Introduction}

Food security only exists when all people, at all times, have physical, social and economic access to sufficient, safe and nutritious food to meet their dietary needs and food preferences for an active and healthy life. The human right to adequate food is recognized by all peoples of the world including their governments.

Teso sub-region of Uganda is an area of $12,182 \mathrm{sq} . \mathrm{km}$ (about $80 \%$ is cultivable) and has a human population of about 2,364,569 (Olupot, 2017) that grows at about 3.2\% per annum (UBOS, 2014; Fountain Publishers, 2011). It is located in North-Eastern Uganda consisting of eight districts of Amuria, Bukedea, Kaberamaido, Katakwi, Kumi, Ngora, Serere and Soroti (see them numbered 1-8 in Figure 1). Also in Figure 1, Bududa is numbered as 9 and Kiryandongo as 10 . The sub-region houses the Teso agricultural system. The system is typified by the growing of annual crops including the sweet potato; keeping of livestock especially cattle (Osekeny, 1996). All these agricultural activities flourish on fairly good climate; and on four moderately fertile soil catenas of Amuria, Bukedea, Buruli and the Usuk series that give Teso mostly sandy loam soils ideal for the sweet potato \& also accommodating some pockets of clay loams. Brady (1974) defined catena as a unit of soils of similar age, parent materials and climatic conditions while a series is a family division of soils that are alike in the main profile characteristics. The Ugandan soils and climate, despite climate change effects, can support the growth of nearly 200 different crops and different classes of livestock (Mukiibi, 2001). Teso farmers can grow over ten adaptable crops namely cassava, maize, finger millet, sorghum, rice, groundnuts, beans, cow peas, green grams, simsim, sunflower, citrus, mangoes, cashew nuts \& cotton including the sweet potato and keep livestock especially cattle (Osekeny, 1996). Additional to cereals such as finger millet and sorghum with groundnuts as legume, the sweet potato and cassava stand out strongly as food security crops that do well in Teso (Mukiibi, 2001). The sweet potato is more strategic because it bears no threat of cyanides that may be found in cassava and to a less extent in some sorghum varieties. In addition, the crop matures faster (one or two varieties such as Odiopelap in a month). 
It is adaptable and the orange fleshed sweet potato varieties are well endowed with Vitamin A important in the human diet.

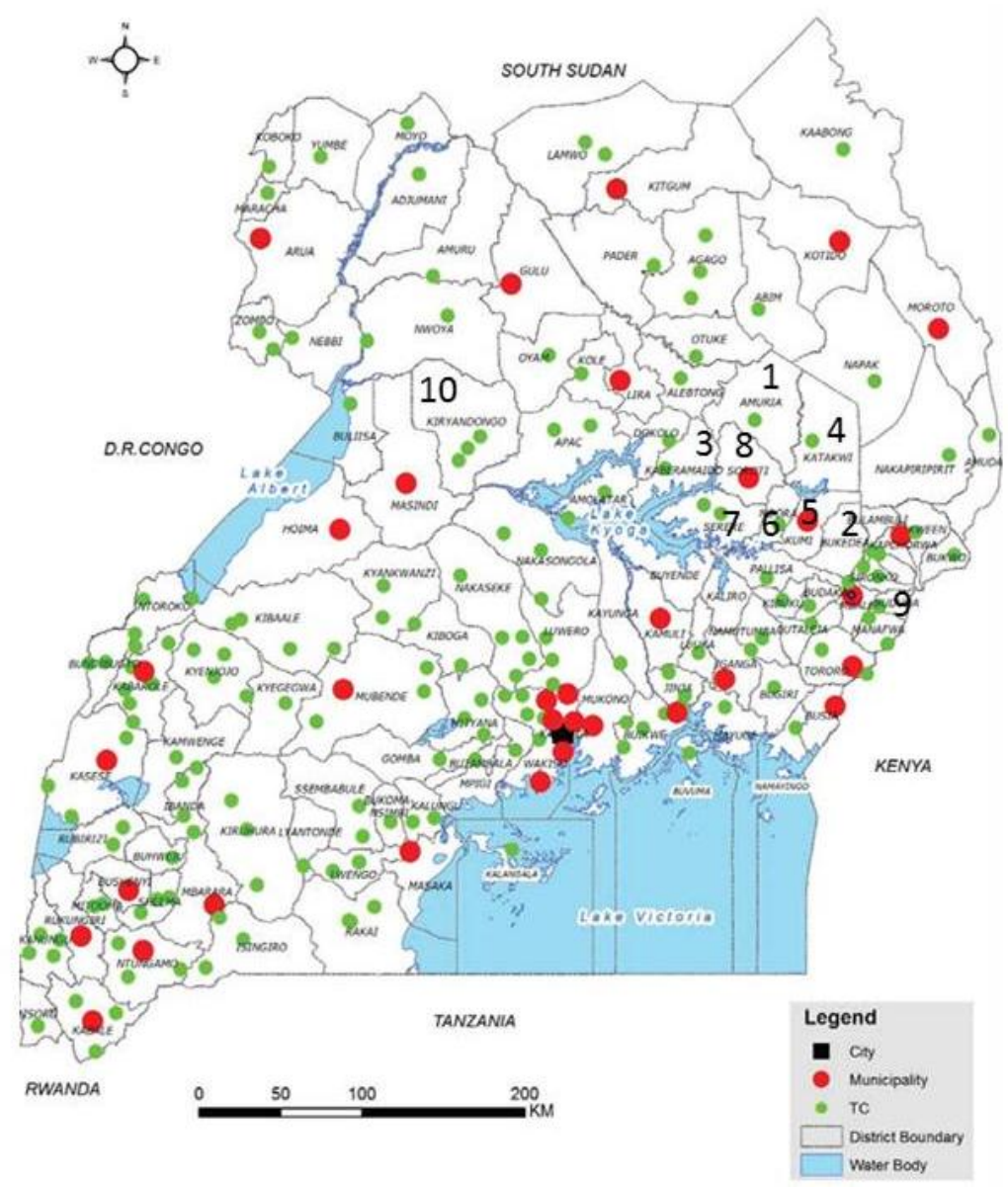

Figure1. Map of Uganda showing Districts and Urban Centres as of March 2016

Source: Uganda Bureau of Statistics. (2016).

\section{Food Production in the Teso Sub-Region to Meet All-time Needs}

Production of food including sweet potatoes in Teso depends on many crosscutting issues supported by the agricultural research system which integrates and interlinks with the different sectors (crops, livestock, fisheries, environment, and natural resources). Consequently, any innovations, knowledge and technologies to bear fruitful interventions should ultimately generate sustainable output and incomes for food security. That requires enhanced farmers' access to needed agricultural information \& mechanization, conducive policies, suitable entrepreneurial skills, knowledge including attitudes and values for success. Food production in the Teso sub-region heavily relies on the expanded and sustainable use of oxen for primary and secondary cultivation (Musiitwa \& Komutunga, 2001). The system is characterized by division of labour by gender where men open the land through ox-cultivation while the women carry out most of the work up to post harvest handling of the produce. Climate change caused by extreme drought sometimes experienced and flush floods with declining soil fertility have intermittently disturbed the effectiveness of the system. The Government of Uganda and Civil Society Organizations have taken steps in the past to address the food security situation in the sub-region through cattle restocking, relief aid, agricultural research and extension among others (Mukotani, 2007). A number of studies highlight the food insecurity in the Teso sub-region (Epeju, 2003) and in the environs such as that in the landslide disaster district of Bududa overlapping to Kiryandongo District where Bududa survivors were resettled (Rukondo, 2016). This article highlights the search for long lasting solutions such as smart agriculture to food insecurity problems wherever they reared their heads (Esenu, 2005; TPO, 2008; Parliament of Uganda, 2009). Sweet potatoes, cassava, groundnuts, millets and cattle always stood out as the prime determinants of food security in Teso. Incomes among people in Teso are generally lower than the national average of 600 US dollars 
per annum and so purchasing power is low to assure food security.

\section{Sweet Potato Production in Teso}

The sweet potato (Ipomoea batatas $(\boldsymbol{L}$.) Lam ) which is highly adaptable to the soils and climate in Teso, is one of the top two crops with cassava (Manihot esculenta Crantz) in the sub-region important for food security. In Uganda, Teso is one of the leading producers of sweet potatoes (Mwanga \& Ssemakula, 2011; Otieno, 1999; Bashaasha et al, 1995). Nationally, it ranks third among the staple food crops after cassava and bananas (National Agricultural Research Organisation, NARO, 2001). Yields of the crop in Teso are sometimes as low as 4 metric tonnes $(4,000 \mathrm{~kg})$ per hectare on farmers' fields instead of the 30 metric tonnes $(30,000 \mathrm{~kg})$ per hectare obtained in the area under research stations (Bank of Uganda, 1992). Per capita production of sweet potatoes yearly in the early $1990 \mathrm{~s}$ was about $95.4 \mathrm{~kg}$ grown on $0.1-0.6$ ha of a subsistence farm against the consumption per capita of $58 \mathrm{~kg}$ (Mwanga \& Ssemakula, 2011; Bashaasha, 1995; Woolfe, 1992) which was about 14\% and 8\% respectively of the food requirement per capita of $700 \mathrm{~kg}$ in a year. The World Bank (1993) estimated a food per capita output of 960 kilogrammes for Uganda yearly coming from crops alone, but a lower figure of $500 \mathrm{~kg} \mathrm{per}$ capita per year for areas such as Teso sub-region, a figure which may presently be slightly higher than the sub-Saharan food a yearly per capita average of 300kg (Kennedy, 2003; Food and Agriculture Organization, 2000). The sweet potato is an important food security crop which alone can supply $429 \mathrm{~kg}$ per capita yearly for the Teso population and is a good source of income in Teso (Epeju, 2003).

\section{Methodology}

This paper is based on findings from two independent studies. The first study investigated sweet potato production within the context of farmer education influence in Teso during the period between 2001 and 2003 (Epeju, 2003). Using an ex post facto design, 24 out of 51 sub-counties were purposively selected based on district data and farmers' level of engagement in sweet potato growing. Accordingly, they were used to determine the perceptions of sweet potato farmers and of their agricultural advisors (Cashwell, 2002; Edwards, 2002; Kothari, 1992; Wiersma, 1986). A total of 650 persons (288 farmers randomly selected, 33 agricultural advisors and 329 community leaders) participated to also establish food and income levels from the crop. Data were analysed qualitatively under themes, categories and subcategories; and quantitatively using means, frequencies, percentages, and multiple regressions at a confidence level of $0.05(\alpha)$ (Strauss \& Corbin, 1990; Microsoft SPSS Version 8, 1998). Sweet potato varieties used in production are shown in Table 1. Literature search was done on its income with other crops.

The second study investigated the human right to adequate food in the context of disaster in the neighbouring Bududa District and in the away Kiryandongo District where the Bududa disaster survivors were relocated during the period between 2012 and 2016 (Rukondo, 2016). Teso has suffered several disasters such as floods and severe droughts which led to relocation of survivors as in Bududa. Rukundo's study gave some good lessons to Teso in dealing with the human right to adequate food. The study used an inter-disciplinary cross-sectional survey design to get perceptions of duty bearers and rights holders. Duty bearers were those who handled survivors and 52 were purposively selected from relevant State institutions. Rights holders were 1,200 household heads of those households which were affected in 2010 by the landslide disaster. Through a three-stage simple random sampling, the affected households were selected giving the household heads in the sample. Using interviews, a total of 1078 household heads were done for complete statistical analysis. Focus group discussions were also held for groups of youth, 18-35 years old $(n=4)$, adult women $(n=4)$, and men $(n=4)$. A total of 1,142 persons were consulted on the right to adequate food. Qualitative data were transcribed and triangulated by clustering and patterning of information, complemented by relevant literature reviews.

Combining results of the two studies Epeju (2003) in Teso and Rukundo (2016) in tracking the handling of the Bududa survivors resettled in Kiryandongo regarding the human right to adequate food was enlightening to handling food insecurity situations such as those in Teso. Food insecurity situations whenever they occurred in Teso as elsewhere in Uganda called the support of many local and international partners employing several duty bearers for the situation from several institutions. Some findings from Rukundo (2016) were relevant in this article to understand how crops such as sweet potatoes can address human rights to adequate food.

\section{Results and Discussion}

\subsection{Sweet Potato Production Level in Teso Sub-region}

The production output, other factors remaining favourable, largely depended on the varieties used by farmers for production. The common varieties used by farmers in the sub-region over the research period and during the last three decades are shown in Table 1. 
Table 1. Sweet potato cultivars used by sweet potato farmers of the Teso sub-region

\begin{tabular}{lccc}
\hline Variety (Cultivar)/Root Colour & $\begin{array}{l}\text { Root Yield t/ha on } \\
\text { Farm (NATIONAL) }\end{array}$ & $\begin{array}{l}\text { Root Yield on Research } \\
\text { Station t/ha }\end{array}$ & Released \\
\hline Bwanjule (white) & 17 & $21(7-49)$ & 1995 \\
New Kawogo (white) & 17 & $23(6-45)$ & 1995 \\
Sowola (cream) & 18 & $29(9-41)$ & 1995 \\
Wagabolige (white) & 16 & $24(6-79)$ & 1995 \\
Tororo-3 (Cream) & 16 & $21(5-52)$ & 1995 \\
Tanzania (pale yellow) & 21 & $23(5-58)$ & 1995 \\
NASPOT 1(pale yellow) & 20 & $29(7-45)$ & 1999 \\
NASPOT 2 (cream) & 18 & $21(7-33)$ & 1999 \\
NASPOT 3 (cream) & 17 & $25(5-29)$ & 1999 \\
NASPOT 4(pale yellow) & 18 & $21(5-38)$ & 1999 \\
NASPOT 5 (orange) & 16 & $23(7-28)$ & 1999 \\
NASPOT 6 (white) & 18 & $24(7-28)$ & 1999 \\
Ejumula (orange) & 15 & $19(2-32)$ & 2004 \\
Kakamega(pale orange) & 12 & $15(4-36)$ & 2004 \\
NASPOT 7(pale orange) & 12 & 25 & 2007 \\
NASPOT 8(pale orange) & 16 & 20 & 2007 \\
NASPOT 9 (orange) & 13 & 20 & 2007 \\
NASPOT 10 (orange) & 12 & 18 & 2007 \\
DIMBUKA-BUKULULA (cream) & 16 & 30 & 2007 \\
NASPOT 11 (cream) & 20 & 38 & 2010 \\
NASPOT 12 (orange) & 16 & 43 & 2013 \\
NASPOT 13 (orange) & 11 & 25 & 2013 \\
\hline
\end{tabular}

${ }^{1}$ Root flesh colour is shown in parentheses against names of varieties. ${ }^{2}$ Root yield ranges on Research stations are indicated for some varieties where the sources gave them.

Sources: Mwanga et al. (1995, 2007); National Crops Research Institute NaCRRI) and National Agricultural Research Organization (NARO). (2010, 2013).

Table 1 shows several releases of 22 sweet potato varieties used by farmers within the period of research and updated to 2013. The orange fleshed sweet potato varieties (OFST) are critical because of the affordable supply of vitamin A they contain in the diet providing improved food and nutrition security especially for malnourished children and pregnant women. Epeju (2003) found that there were different yield levels from on-farm trials across farms nationally. There were no varieties yielding at low and medium levels $(0-5,000 \mathrm{~kg} / \mathrm{ha}$ and $5,001-9,000 \mathrm{~kg} / \mathrm{h}$ a respectively). Nineteen varieties (19) fell in the high yield level of 9,001-19,000 kg/ha and three (3) were in the very high yield level of $19,001-29,000 \mathrm{~kg} / \mathrm{ha}$. No varieties yielded at the excellent level of more than $29,000 \mathrm{~kg} / \mathrm{ha}$. The national average yield from on-farm trials was $16,000 \mathrm{~kg} / \mathrm{ha}$, which was higher than $7,138 \mathrm{~kg} / \mathrm{ha}$ the average found on Teso farms (Epeju, 2003).

Table 2 shows the output of sweet potatoes possible from the farmers of the entire Teso sub-region. Using the data available on the cultivable land area per district in Teso (Fountain Publishers, 2011), the possible area that can be put under sweet potato per season per year was determined based on the finding that in Teso $11 \%$ of household farm size annually is put under sweet potato production. Therefore, Table 2 gives the output using that area computation for each district multiplied by the sub-region average of $7,138 \mathrm{~kg} / \mathrm{ha}$ of sweet potato production to give output per district in metric tonnes (Epeju, 2003). Over the few years, the average is still valid considering the climatic change effects that have prevailed in the area. 
Table 2. Output of Sweet Potatoes possible on farms in Teso sub-region per season yearly

\begin{tabular}{cccc}
\hline DISTRICT & $\begin{array}{c}\text { AREA UNDER SWEET } \\
\text { POTATOES IN HECTARES }\end{array}$ & OUTPUT IN TONNES & PERCENTAGE \\
\hline Amuria & 28,336 & 202,262 & $20 \%$ \\
Bukedea & 11,572 & 82,601 & $8 \%$ \\
Kaberamaido & 17,908 & 127,827 & $13 \%$ \\
Katakwi & 27,247 & 194,489 & $19 \%$ \\
Kumi & 11,825 & 84,407 & $8 \%$ \\
Ngora & 7,942 & 56,690 & $6 \%$ \\
Serere & 21,604 & 154,209 & $15 \%$ \\
Soroti & 15,521 & 110,789 & $11 \%$ \\
TOTAL & $\mathbf{1 4 1 , 9 5 5}$ & $\mathbf{1 , 0 1 3 , 2 7 5}$ & $\mathbf{1 0 0 \%}$ \\
MEAN & 17,744 & 126,659 & - \\
\hline
\end{tabular}

Considering the current population of the Teso sub-region as 2,364, 569 (Olupot, 2017; UBOS, 2014), it means the sub-region's sweet potatoes alone can supply $429 \mathrm{~kg}$ per capita yearly for its population which is $61 \%$ of the projected $700 \mathrm{~kg}$ of food per capita yearly. The yields are those from fresh roots. It also means that sweet potatoes is an important food security crop in Teso although it may not be as tolerant as cassava to common dry spells in Teso.

Incomes of farmers in the sub-region continue to be low (no more than 300 (three hundred) US dollars per capita). Epeju (2003) established that sweet potato farmers in Teso earned only US dollars 222 (two hundred and twenty two) per hectare annually through sweet potato sales. Table 3 shows resulting incomes computed but using current prices as of March 2017 and using yield levels on farms for the common crops grown in Teso as estimated by the Bank of Uganda (1992). Twenty five years later, yields in the area, have remained low and in some cases declined. Proceeds from livestock have been left out in the computation although they often cushioned the incomes of farmers in Teso. Although the other farm enterprises in terms of income were not in the study of 2003, using literature search to compare with sweet potato incomes was done as shown in Table 3. 
Table 3. Income of farmers as of March 2017 possible in Teso from common crops including sweet potatoes using yields per hectare based on 1992 levels on-farm

\begin{tabular}{|c|c|c|c|c|}
\hline CROP ENTERPRISE & $\begin{array}{l}{ }^{1} \text { YIELD/HA'IN } \\
\text { KG }\end{array}$ & $\begin{array}{c}{ }^{2} \text { CURRENT } \\
\text { PRICE (UShs: US } \\
\text { \$) PER KG }\end{array}$ & $\begin{array}{c}\text { INCOME EXPEXTED } \\
\text { IN UShs: US \$) }\end{array}$ & $\begin{array}{l}\text { PERCENT } \\
\text { INCOME } \\
\text { EARNED }\end{array}$ \\
\hline \multirow[t]{2}{*}{ Sweet potatoes (fresh) } & 7,500 & UShs: 980 & UShs:7, 350, 000 & \\
\hline & & US \$: 0.27 & US \$: 2, 025 & $26 \%$ \\
\hline \multirow[t]{2}{*}{ Cassava (fresh) } & 4,442 & UShs: 1,000 & UShs: 4,442,000 & \\
\hline & & US \$: 0.28 & US \$: 1,244 & $16 \%$ \\
\hline \multirow[t]{2}{*}{ Finger millet (dry) } & 916 & UShs: 2,200 & UShs:2,015,200 & \\
\hline & & US \$: 0.61 & US \$: 559 & $7 \%$ \\
\hline \multirow[t]{2}{*}{ Maize (grain) } & 1,000 & UShs: 1,400 & UShs: $1,400,000$ & \\
\hline & & US \$: .39 & US \$: 390 & $5 \%$ \\
\hline \multirow[t]{2}{*}{ Sorghum (grain) } & 1,596 & UShs: 1,250 & UShs:1,995,000 & \\
\hline & & US \$: 0.35 & US \$: 559 & $7 \%$ \\
\hline \multirow[t]{2}{*}{ Groundnuts (grain) } & 1,000 & UShs: 5,550 & UShs: $5,550,000$ & \\
\hline & & US \$: 1.54 & US \$: 1,540 & $19 \%$ \\
\hline \multirow[t]{2}{*}{ Beans (grain) } & 954 & UShs: 2,800 & UShs: 2,671, 200 & \\
\hline & & US \$: 0.78 & US \$: 744 & $9 \%$ \\
\hline \multirow[t]{2}{*}{ Cowpeas (grain) } & 400 & UShs: 4,050 & UShs: $1,620,000$ & \\
\hline & & US \$: 1.13 & US \$: 452 & $6 \%$ \\
\hline \multirow[t]{2}{*}{ Simsim (grain) } & 300 & UShs: 5,000 & UShs: $1,500,000$ & \\
\hline & & US \$: 1.39 & US \$: 417 & $5 \%$ \\
\hline TOTAL FOOD & 18,108 & UShs: 1,576.27 & UShs: $28,543,400$ & \\
\hline IN KG & & US \$: 0.438 & US \$: 7,930 & $100 \%$ \\
\hline
\end{tabular}

${ }^{1}$ Yield levels per ha for 1992 were used (Bank of Uganda, 1992) because yields have not really changed very much since then representing national average yields on-farm for those crops.

${ }^{2}$ Current prices used were taken from average commodity prices for the week as at March 27, 2017 in order to determine the possible income per hectare from those crops (Infotrade Uganda, 2017).

Table 3 data allows one to demonstrate how the sweet potato as a crop can contribute to food security and income in Teso where it is a very important food crop that continued to earn income after the collapse of cotton as a cash crop (World Bank, 1993). Orange fleshed sweet potatoes from Teso sub-region are well known in Kampala City, Uganda's national capital. Per capita production of sweet potatoes per year in Uganda is $125 \mathrm{~kg}$ against the per capita consumption of $85 \mathrm{~kg}$ per year (Mwanga \& Ssemakula, 2011; Woolfe, 1992). The consumption is about $12 \%$ of the yearly expected food per capita of $700 \mathrm{~kg}$. In Table 3, although yields in the Teso sub-region may be lower than the national averages for the nine crops presented, as an income earner sweet potaoes stand at $26 \%$ contribution of the nine food crops to income signifying that it adds to food security through access to food. It is known from research that $11 \%$ of every smallholder farm in Teso is put under sweet potatoes annually yielding over $4,000 \mathrm{~kg} \mathrm{ha}^{-1}$ thus an income of over UShs. 3,000,000/= per annum (about US dollars 1000, one thousand) other factors remaining favourable (Epeju, 2003). Yield ha ${ }^{-1}$ in Teso of sweet potatoes is known to lie between 4,000 and $7,500 \mathrm{~kg}$.

\subsection{The Human Right to Adequate Food}

Rukundo (2016) vividly described the Bududa disaster situation on the human right to adequate food. There are several lessons from his study for Teso, Uganda and the rest of humanity. The struggle for equality in availability and access to adequate food and the means for its procurement have been known globally from time immemorial (Andreassen, 2007). Through agriculture, Teso sub-region and Uganda as a country continue to strive to assure food security to all citizens through existing laws such as the Constitution of the Republic of Uganda (GOU, 1995) \& the law on Food and Nutrition (2009). There are also conducive policies supporting the implementation of the human right to adequate food such as the Food and Nutrition Policy (2003), Uganda Nutrition Action Plan 2011-2016 ( GOU, 2011), and the National Policy on Disaster Preparedness and Management, Government of the Republic of Uganda. Sweet potatoes is one of those crops farmers are encouraged to produce for good food security additional to others shown in Table 3 because it is more adaptable to moderate drought with its quicker maturing thus meeting the pillars of smart agriculture namely adaptation, mitigation and sustainability. Unlike 
cassava the king pin root crop on food security in Uganda, it does not contain cyanides and has more affordable Vitamin A through the orange fleshed sweet potato varieties. Masaba et al. (2017), under the current food shortage countrywide caused by the ravaging drought of 2016-2017, reported the story of two parents in Teso sub-region mourning their 12-year old who died after eating immature cassava. The parents said: "We opted to uproot our cassava and dried it before making bread out of its flour. However, the bread was bitter but we insisted on eating it. The boy started vomiting and developed a running stomach. He died on arrival in hospital." Another two parents in the same sub-region lamented saying they had also lost a son from eating bitter cassava. It shows that although cassava has been known to be a good famine crop, it has varieties that may have high levels of cyanides which are poisonous. Like cassava, sweet potatoes can be used as fresh roots which can store in the ground for a while, and through slicing or crushing the roots they can be dried and used as chips or flour later but without the serious dangers of poisonous cyanides. Free from cyanides sweet potatoes has a high potential as a food crop for famine or disaster situations.

Although Teso, as a part of Uganda, is well covered through the clear recognition of the right to adequate food by the country's constitution and policy framework according to Rukundo (2016), the system seems constrained to timely deliver on its promises. Policy does not match with prudent legislation to appropriate funds and institutional investment to implement related obligations to vulnerable victims of disaster or famine caused by conditions of bad weather/floods or emergency circumstances such as war, landslides and earthquakes. The absence of ready preparedness of capabilities seem to exacerbate the institutionalization of a minimum humanitarian approach of mainly short-term relief to prevent hunger and starvation at the expense of a desirable right to adequate food approach. The key finding of the study stressed that it is of imperative necessity that the responsible actors and relevant processes respond by investing more considerable resources to strengthen local, national and institutional capabilities for rights-based early warning and surveillance, risk mitigation and adequate relief operations, among others. Both at the local, national and regional levels, it is imperative to build food stores especially of sweet potatoes with value addition for emergencies through creating sustainable and secure food silos and cereal banks. Households through legal and policy frameworks should be supported to have sustainable and secure food stores of their own for emergency situations through crops such as sweet potatoes.

\subsection{Meeting the Human Right to Adequate Food under Disasters in Teso through Sweet Potatoes}

Disasters occur in a number of forms in isolation or in combination with different causes. Uganda has had several of them namely civil wars, earthquakes, landslides, floods, severe long droughts, severe pest and disease attacks on animals, crops and humans. All of them have led to shortages of food. Teso has had a share of such disasters. During the period of civil strife (1986-1995) and floods in Teso, it is widely known there that sweet potatoes rescued many families with food and income. Consequently, food and the struggle to access it have influenced the political development of and life in states of the world (Andreassen, 2007). Food also has strong influence on global stability affecting international trade, and global health associating with lifestyle and behavior (Lang \& Heasman, 2004). The Constitution of the Republic of Uganda adopted on $12^{\text {th }}$ May, 1999 declared on accessibility to food sustainably through the establishment of institutional structures, policies such as research in sweet potato production and legislation to ensure that hunger and all forms of malnutrition are prevented in a dignified way. The Uganda Government pledges through its different policies to ensure food security and adequate nutrition services among its people under all circumstances including disasters and emergency situations (GOU, 1995; 2003, 2009; 2010 and 2011).

Rukundo (2016) findings on the human right to adequate food underscore the role of sweet potatoes for food and income in Teso. They also provide a lesson that land is indeed an important source of food and income that guarantees a more stable food security situation with both higher food variety scores and diet diversity scores for nutrition security. Sweet potatoes have a great possibility of supporting the human right to adequate food in Teso.

\section{Conclusions and Recommendations}

Sweet potato yields and the possible income from it underline its great potential for food security in Teso and beyond. In addition, they give the affordable supply of Vitamin A and minerals from orange fleshed sweet potato varieties, without any cyanide dangers, enhances its place in improving the diets assuring nutrition security especially of the pregnant women and the many malnourished children in Uganda lacking Vitamin A. In Teso, there are possibilities of expanding and improving the land base to increase farm productivity other conditions remaining favourable. Although intermittently, there are challenges in the economy and of climate change effects which distort production, it is strategic to develop the processing of the sweet potato roots for value addition to get products of a longer shelf-life such as chips, flour, fortified food, drinks and confectionery products. Sensitizing farmers through early warning by agriculture and disaster experts, farmers can participate better and 
contribute more to the human right to adequate food in Teso and beyond, through building sustainable food stores such as cereal banks, granaries and silos, enabling the country to deal firmly with situations of disaster and emergency on food.

\section{Acknowledgements}

The authors would like to thank the authorities of Kyambogo University for responsibility and opportunities given. Thanks to all colleagues for sharing opportunities. All peoples of the world, your rights to adequate food ought to be assured by United Nations and all Governments of the World through affirmative action and appropriate policies with adequate financial support.

\section{References}

Andreassen, B. A. (2007). Political science, human rights and the right to food discourse. In Eide, W.B., Kraucht, $\mathrm{U}$ (eds) Food and human rights in Development: Evolving issues and emerging applications II, Antwerpen and Oxford: Intersentia, pp 81-104.

Bank of Uganda, (1992). Yields of Export Crops per hectare, Kampala, Uganda

Bashaasha, B., Mwanga, R. O. M., Ocitti p'Obwoya, C., \& Ewell, P. T. (1995). Sweet potato in the farming and food system: A farm survey report. International Potato Center Sub-Saharan Africa Region, Nairobi, Kenya.

Brady, N. C. (1994). The nature and properties of soils ( $8^{\text {th }}$ ed.), New York, NY: Macmillan Publishing Co. Inc, pp 598, 618, 639.

Cashwell, G.S. (2002). Descriptive research methods. Retrieved from http://ericcas.uncg.educ/research/cashwell.html

Edwards, A. W. (2002). Non-experimental quantitative research. Retrieved from http://kancrm.kckps.k12.ks.us/guide/nonexperimental.html

Epeju, W. F. (2003). Farmers' and Agricultural advisers' perceptions on the role of education in sweet potato (Ipomoea batatas, L.) production in Teso, Uganda, Unpublished PhD Thesis, Egerton University, 278 pp.

Esenu, N. B. (2005). Gender relations in livestock production and ownership: Implications for household food security in the Teso farming system (TFS), Unpublished MSc Thesis, Kampala,Uganda: Faculty of Agriculture, Makerere University, 92pp. Available at http://smallstock.info/research/proj/R8108.htm on 13-10-2010

Food and Agriculture Organization. (2000). FAO online data. Retrieved from http://apps.fao.org

Fountain Publishers. (2011). UGANDA DISTRICTS Information Handbook (Ninth Edition),Kampala, Uganda, Foutain Publishers, 113-115, 147-149, 172-174, 372pp.

Government of Uganda, GOU. (1995). Constitution of the Republic of Uganda, Republic of Uganda, Kampala, Uganda. Retrieved from http://statehouse.go.ug/sites/default/files/attachments/abridged.1995.pdf accessed on 20th February, 2013

GOU.(2003). Uganda Food and Nutrition Policy, Ministry of Agriculture, Animal Industry and Fisheries and Ministry of Health, Kampala, Uganda.

http://extranet.who.int/nutrition/gina/sites/default/filesUGA\%202003\%2Uganda20\%and\%Nutrition\%Policy .pdf. Accessed on 9-8-2013.

GOU. (2009). Food and Nutrition Draft Bill, Kampala, Uganda. http://www.heallth.go.ug/nutrition/docs/population/FOOD AND NUTRITION.BILL_2009.pdf Accessed on 10-9-2013.

GOU.(2010).National Policy of Disaster Preparedness and Management of the Uganda, Kampala. http://www.opm.go.ug.assests/media/resources/8/Disaster\%20Policy.pdf. Accessed on 3-8-2013.

GOU. (2011). Uganda Nutrition Action Plan 2011-2016, National Planning Authority, Kampala, http://www.health.go.ug/docs/NAP.11.16.pdf. Accessed 1-9-2013.

Infotrade, Uganda. (2017). Market Information Services: Current prices for the Week, Average Commodity Prices as at 27, 2017. http://www.infotradeuganda.comindex.php/marketinformationhtml. Accessed on 2-5-2017.

Kennedy, G. (2003). Food security in the context of urban sub-Saharan Africa: Internet Forum of FoodAfrica. Available at http://www.foodAfrica.nri.org on 23-9-2011 in the Proceedings of FoodAfrica:Forum $\left(31^{\text {st }}\right.$ March 2003-11 ${ }^{\text {th }}$ April,203). 
Kothari, C.R. (1992). Research Methodology: Methods and Techniques (Second Edition), New Delhi, India: Wiley Eastern Limited, pp 352-358, 468pp.

Lang, T., \& Heasman, M. (2004). Food wars: the global battle for mouths, minds and markets: Eathscan.

Masaba, J., Olandason, W., Ojore,G., Okethwengu, B., Kiva, N., Bikala, Obol, W., Asimwe,W. (2017). Hunger ravages the Pearl of Africa. Saturday New Vision Newspaper, 11(17) (May 6, 2017), Kampala, Uganda: The New Vision Printing and Publishing Co.Ltd, pp 12-13.

Microsoft Windows. (1998). The Statistical Package fo Social Sciences (SPSS, Version 8.0, Chicago,USA: Dell Company.

Mosher, A. T. (1966). Getting Agriculture Moving, New York, USA: Agricultural Development Council.

Mukiibi, J. (ed) (2001). Agriculture in Uganda II Crops, NARO, Kampala, Uganda: The Fountain Publishers, 572 .

Mukotani, R. (2007). Teso region flood victims need Shs.120billion urgent relief. Policy Review newsletter Vol. 7, issue 8; Retrieved on $28^{\text {th }}$ September 2011 from the Uganda Debt network website: http://www.udn.or.ug/pub/prn-Septmber2007.pdf

Musiitwa, F., \& Komutunga, E. T. (2001). Agricultural systems. In J. K. Mukiibi (Ed.), Agriculture in Uganda. Kampala: National Agricultural Research Organisation (NARO)Fountain Publishers.

Mwanga, R. O. M., Odongo, B., Alajo, A., Kigozi, B., Niringiye,C., Kapinga, R., \& Yencho, C. (2007). Release of two orange fleshed sweet potato (OFST), cultivars, Kakamega (SPK004) and 'Ejumula' HortScience, 42(7), 1728-1730.

Mwanga, R. O. M., Odongo, B., Smit, N., p'Obwoya, C. O., \& Gibson, R. (1995). Submission to the variety release committee for release of sweet potato varieties, 1995, and Namulonge Agricultural and Animal Production Research Institute (NAARI), Kampala, Uganda.

Mwanga, R. O. M., \& Ssemakula, G. (2011). Orange fleshed sweet potatoes for food, health and wealth in Uganda. International Journal of Agricultural Sustainability, 9(1), 42-49. https://doi.org/10.3763/ijas.2010.0546

National Crops Research Institute (NaACRRI) \& National Agricultural Research Organisation (NARO), (2010, 2013). Submission to the variety release committee for release of sweet potato varieties, Entebbe, Uganda: Republic of Uganda.

National Agricultural Research Organisation (NARO). (2001). Agriculture in Uganda II Crops, NARO (Edited by J.K. Mukiibi), Kampala, Uganda: The Fountain Publishers, 572p.

Olupot, G. (2017). Citrus pests, diseases threaten Teso juice factory. In The New Vision Newspaper, Vol. 32, No, 82, (Tuesday, April 25, 2017): Kampala, Uganda: The New Vision Printing and Publishing Co. Ltd, pp 24-25.

Osekeny, J. C. (1996). Kumi restocks 20,000 cows. In The New Vision Newspaper, Vol. 11, No, 44, (Wednesday, $21^{\text {st }}$ February, 1996): Kampala, Uganda: The New Vision Printing and Publishing Co. Ltd, p 13.

Otieno, J. O. (1999). Securing food security or cashing opportunities: The changing roles of sweetpotato in Northeast Uganda. A paper presented at $42^{\text {nd }}$ Annual meeting of African Studies Association, Philadelphia, Pennsylvania, USA, November 14-18, 1999: International Potato centre.

The Parliament of Uganda.(2009). Report of the Committee on Agriculture, Animal Industry, and Fisheries on the Famine Situation in Teso Sub-region, Kampala, Uganda: Republic of Uganda: Available at http://H: AAIF- Famine Situation in Teso Sub-region on 23-9-2011, 21pp.

Rukundo, M. P. (2016\}. The Humn Right to Adequate Food in the Context of Disaster: The Case of the Major 2010 Landslide in Eastern Uganda, Oslo, Norway, PhD Dissertation, Faculty of Medicine, University of Oslo

Strauss, A., \& Corbin, J. (1990). Basic of qualitative research: Grounded theory procedures and techniques, Newbury, Park, California, USA: Sage Publications, 15-194.

Transcultural Psychological Organisation, TPO. (2008). Farming, livelihoods and food security, a case study in Teso.Available at http://www.tpoug.org/paul-case study-teso.shtml accessed on 12-10-2010.

Uganda Bureau of Statistics. (2014). National Population and Housing Census 2014: Provisional Results ( November, 2014, Revised Edition ). Kampala, Uganda, 65 pp: Available at www.ubos.org accessed on 
17-3-2015.

Uganda Bureau of Statistics. (2016). The National Population and Housing Census 2014-Main Report, Kampala, Uganda.

United Nations Administrative Committee on Coordination. (2000). System wide guidance on household food security and nutrition. Occasional Paper.

Wiersema, W. (1986). Researh methods in education: An Introduction (Fourth Edition)Boston, USA: Allyn and Bacon Inc. pp 15, 171-217, 354-359, 466p.

Woolfe, J. A. (1992). Sweetpotato: An untapped food reserve, New York, New York: Cambridge University Press, pp 15-40.

World Bank. (1993). Uganda: Agriculture (AWorld Bank Survey), Washington, D.C., USA: A World Bank Publication, pp viii, 1-16, 143-172.

\section{Copyrights}

Copyright for this article is retained by the author(s), with first publication rights granted to the journal.

This is an open-access article distributed under the terms and conditions of the Creative Commons Attribution license (http://creativecommons.org/licenses/by/3.0/). 